\title{
Por uma Valorização da Formação Inicial no Curso de Licenciatura em Matemática
}

\author{
Barbara Corominas Valério* \\ Instituto de Matemática e Estatística da Universidade de São Paulo
}

* Autor para correspondência: barbarav@ime.usp.br

\section{RESUMO}

Reconhecendo a importância do estágio de regência na formação inicial do professor, o IME-USP criou em 2009 um Programa de Estágios Supervisionados para o curso de Licenciatura em Matemática. O presente trabalho descreve como esse programa é desenvolvido, explicitando o vínculo gerado entre o IME-USP e a escola de Educação Básica. Como exemplo, é apresentado um projeto desenvolvido em 2014 sob a minha supervisão. Além disso, este trabalho traz indicativos de quão importante foi a implantação do programa na formação dos licenciandos do IME.

Palavras-chave: Formação inicial; Formação Continuada; Estágio Supervisionado.

\begin{abstract}
Recognizing the importance of conducting training in initial teacher education, the IME- USP created in 2009 a Supervised Internship Program for Teachers Training Course in Mathematics. This paper describes how this program is developed, explaining the link generated between the IME- USP and the school of Basic Education. As an example, it is described a project developed in 2014 under my supervision. Moreover, this work brings indicatives of how important the implementation of the program was in the training of undergraduates of the IME.
\end{abstract}

Keywords: Initial Formation; Continuing Education; Supervised Internship.

\section{Introdução}

Reconhecendo a importância do movimento desencadeado pela Lei de Diretrizes e Bases da Educação Nacional (LDB) 9394/96 no tocante à necessidade de uma revisão e atualização das formações inicial e continuada de professores, a Universidade de São Paulo aprovou, em 2004, o Programa de Formação de Professores da USP (PFP-USP). Pode-se afirmar que um dos princípios norteadores do PFP-USP é promover uma formação inicial comprometida com as necessidades da escola pública, no sentido de que as atividades desenvolvidas pelos licenciandos contemplem uma forte articulação com a formação continuada de professores.

Nessa perspectiva, o Instituto de Matemática e Estatística da USP (IME-USP) criou um Programa de Estágios Supervisionados para o curso de licenciatura. A partir de 2009, estão sendo estabelecidas, anualmente, parcerias com escolas públicas, visando a garantir a realização de estágios curriculares obrigatórios dos alunos em instituições de Educação Básica e a apoiar a capacitação contínua dos professores das escolas-campo. Foi criada uma disciplina anual obrigatória de graduação - Projetos de Estágio - e a cada ano, juntamente com esta, é oferecido um curso de extensão para os professores regentes de classe em escola parceira. As atividades conjuntas são desenvolvidas por grupos formados por alunos da Licenciatura (estagiários) e professores da rede (seus supervisores na escola) sob a orientação de um docente do Departamento de Matemática, com o apoio de educadores vinculados ao Programa, selecionados dentre os alunos de pós-graduação da universidade que desempenham um papel fundamental na implementação do programa.

Essas atividades conjuntas visam a promover a elaboração de projetos ou sequências didáticas para serem aplicadas em salas de aula dos ensinos 
fundamental ou médio e a realizar, com base nos projetos elaborados, a supervisão de cem horas de estágio curricular obrigatório de cada aluno.

\section{Desenvolvimento das Atividades}

A concepção do Programa de Estágios Supervisionados do IME teve por fundamento a ideia de que é essencial, no curso de licenciatura, uma proposta integradora entre teoria e prática. Nas aulas práticas essa relação fica explícita, o que vai ao encontro do que defende Nóvoa: "a necessidade de uma formação de professores construída dentro da profissão" (2009, p. 28).

Nessa perspectiva, formam-se grupos compostos por um professor da rede e por estagiários. Cada grupo deve desenvolver um projeto ou uma sequência didática para trabalhar com um tema previsto no plano de aulas do professor para o segundo semestre. Em geral, são escolhidos os temas que os professores têm maior dificuldade em ensinar.

Os estagiários, ao longo do primeiro semestre, devem se familiarizar com as classes envolvidas. São aplicadas atividades diagnósticas, como subsídio ao desenvolvimento do projeto, o que propicia um redirecionamento de objetivos, um aprofundamento teórico das dificuldades encontradas e a determinação de apoios didáticos mais adequados. Já no segundo semestre, com os projetos finalizados, passa-se às suas aplicações, o que frequentemente exige readequações de cronogramas e de atividades. Aplicados os projetos, os grupos devem fazer um relatório que inclui a avaliação dos resultados obtidos.

A fim de viabilizar a elaboração dos projetos, algumas questões de metodologia do ensino de Matemática e, especificamente, de didática são colocadas em discussão. Questões envolvendo resolução de problemas, o uso de jogos e materiais estruturados ou não, e conceitos como contrato didático, transposição didática, registros de representação semiótica, obstáculos didáticos, erros e aprendizagem significativa são naturalmente trazidos para a discussão e reflexão dos grupos.

Os projetos desenvolvidos e aplicados no Programa sob minha supervisão versaram sobre temas diversos, como, por exemplo, alfabetização numérica, as quatro operações fundamentais, frações, geometria, medidas e cálculo mental. A seguir, descrevo o projeto "As Quatro Operações", desenvolvido em 2014, em uma escola municipal da zona oeste da cidade, que envolveu treze alunos com idades entre onze e catorze anos. Todos os alunos envolvidos no projeto já haviam tido contato com o algoritmo das quatro operações, no entanto, em sua maioria, não eram capazes de resolver contas simples, e os que conseguiam apenas reproduziam o algoritmo sem entender o valor posicional dos números e o processo das trocas realizadas.

Constatada essa realidade, o grupo percebeu que reapresentar as quatro operações da forma como os alunos já as tinham visto não seria produtivo, mesmo utilizando recursos como ábaco e material dourado. Seria necessário fazer algo diferente que envolvesse os alunos, principalmente devido à faixa etária na qual eles se encontravam. Decidiu-se trabalhar as quatro operações na base quatro, que possibilitaria compreender-se o valor posicional e o processo de trocas de forma eficiente, sem que os vícios dos estudantes atrapalhassem o processo.

Foram compradas quinhentas unidades de bolinhas de isopor, as quais foram pintadas pelos alunos com três cores: vermelha, verde e amarela, sendo que quatro bolinhas vermelhas equivaliam a uma verde, quatro verdes eram equivalentes a uma amarela e quatro amarelas seriam equivalentes a uma bola azul. A construção do material promoveu um momento de socialização e trabalho em equipe; além disso, os alunos se sentiam motivados em utilizar o material produzido por eles.

Com a aplicação desse projeto, os estagiários tiveram a oportunidade de aplicar atividades diferenciadas contando com todo o suporte teórico nas dificuldades encontradas. É importante relatar que a aplicação do projeto alcançou o seu objetivo, isto é, os alunos aprenderam o significado do valor posicional dos números e os processos de troca, sendo que a maioria deles passou a efetuar de forma correta as quatro operações na base decimal. $\mathrm{O}$ ganho que a supervisora e os estagiários tiveram também merece destaque. 


\section{Resultados}

Após quatro anos, não consecutivos, ministrando a disciplina Projetos de Estágio, percebo, pelos relatos dos alunos, quão valiosas são para o licenciando a realização de um estágio de regência e a existência de uma disciplina que não só lhe oferece a oportunidade de discutir a sua prática, mas também o motiva a exercê-la. Zeichner salienta que "pesquisas têm mostrado claramente que as experiências de campo constituem importantes ocasiões para que se efetive a aprendizagem docente" (2010, p. 484).

Ao questionar os alunos se a disciplina de Projetos de Estágio tinha contribuído para a sua formação como futuros professores, um deles, em 2013 relatou:

Contribuiu muito. Porque foi uma oportunidade de estar diante de uma sala de aula com voz ativa, vivenciando experiências reais com alunos inseridos na educação pública. A cada visita, eu podia descobrir coisas novas sobre o desafio de ser professora e questionar-me sobre essa decisão. É na verdade um exercício de avaliação e autoavaliação constante, e a parte mais difícil é a correção e o lidar com o erro.
Outro aluno, em 2014, declarou: "Este estágio fez com que eu sentisse que estava exercendo a profissão de professor e não somente assistindo a aulas que eu já sabia como funcionariam".

Ainda segundo Zeichner (2010), quando adotamos a postura do ensino reflexivo, assumimos o compromisso de incentivar os futuros professores a desenvolverem as disposições e as habilidades para aprenderem a partir de suas experiências, o que será fundamental ao longo de toda a sua carreira docente.

É importante registrar ainda que temos conseguido promover de forma eficiente uma articulação entre a formação inicial e continuada de professores de Matemática, colaborando, assim, para a diminuição do distanciamento existente entre a Universidade e a Educação Básica.

\section{Referências Bibliográficas}

NÓVOA, A. Professores: Imagens do Futuro Presente. Lisboa: Educa, 2009.

ZEICHNER, K. "Repensando as Conexões entre a Formação na Universidade e as Experiências de Campo na Formação de Professores em Faculdades e Universidades". Educação, Santa Maria, v. 35, n. 3, set./ dez. 2010, pp. 479-504.

"Uma Análise Crítica sobre a 'Reflexão' como Conceito Estruturante na Formação Docente". Educ. Soc., Campinas, vol. 29, n. 103, 2008, pp. 535-554.

Publicado em 11/11/2016. 